\title{
DOES GREEN INNOVATIVE PRACTICES MATTER? THE EFFECT OF GREEN INNOVATION ON GREEN ENTREPRENEURSHIP SUSTAINABILITY
}

\author{
P. Mathushan* \\ Department of Economics and Management, \\ Vavuniya Campus of University of Jaffna, \\ mathush92@gmail.com \\ A. Pushpanathan \\ Department Economics and Management \\ Vavuniya Campus of University of Jaffna \\ pushpa642002@yahoo.com
}

\begin{abstract}
Green entrepreneurs have been realized as critical motorists for a transition to a green economy. There has been a growing interest in developing a 'green' economy as a means of reconciling economic development and the environment. Hence, green entrepreneurs are exchangingfluctuating stiffnesses between their business activities, environmental philosophies, and broader contexts at the intertwine between the green economy and the mainstream economy. However, research on green innovation and green entrepreneurship has been finite focused and remained agnostic in Sri Lankan context.More specifically, entrepreneurs in Vavuniy a district rigorously encountering colossal problems in green innovation (e.g. green packing, green marketing). In fact, there is an urge to foster green innovative practices to reap business success. Hence, the researchers selected entrepreneurs in Vavuniya district. Therefore, the present study aims to investigate the effect of green innovation (innovative practices) on green entrepreneurship sustainability. Data were gleaned from purposively chosen entrepreneurs in Vavuniya district with in-depth interviews. The results revealedthat most informants disclosed that entrepreneurs do not appear to be prepared to encounter the challenges or take unforeseen risks by capitalizing in green business and green innovative practices. Ironically the government and other departments and educational institutions (colleges and universities) do not recognize their role and fail to support green entrepreneurship development.
\end{abstract}

Keywords: Green entrepreneurs; Green entrepreneurship sustainability; Green innovative practices; Sustainability

Journal of Business Studies, 7(1) -1272020 


\section{Introduction}

The impact of entrepreneurship in the progress of societies has been well recognized (Schumpeter, 1934). Although entrepreneurship plays a phenomenal role in facilitating economic growth and sustainable economic development through, innovative products, creating new markets, and generating employment opportunities, previous studies report that the entrepreneurship has been extensively indicted for negative impacts on the society from its business activities. Such unsustainable business practices have been described by researchers as "business-asusual model" (See Mrkajic et al., 2019). More so entrepreneurship considered as creating innovative business ventures that are self-sustaining and value creating activities. entrepreneurship known as the establishment of self-supporting organization. it encapsulates risks and uncertainties in relation to business operations (Jain, 2018; Kengatharan, 2013).

Entrepreneurship has been recognized to assist in invigorating regional identity, making the innovation process more dynamic, and generating new job opportunities (Oecd, 2011). Lucidly, growing interest in entrepreneurship, and more specifically, due to the advent of new innovative entrepreneurs and firms, has fully-fledged among academics and government. Therefore, the interest based on entrepreneurship's contribution to economic growth and sustainable development, through productivity, and revitalized social and productive interactions.

Green entrepreneurship considered as a type of social entrepreneurship, whereas the entrepreneur is passionate to assist environment. Green entrepreneurs motivated by the environmental conscious stand at the heart of greening the economic activities right from their inception. Taylor\&Walley (2004) stated that green entrepreneurs who pursue revenue goals through means of ecological or socially oriented businesses. In the concurrent scenario, risks of climate change are emerging over the world, therefore, there is a sprightly requirement for a sustainable move in the prevailing consumption and production (Haldar, 2018). Green entrepreneurship is not merely about economic earnings in monetary system but it is regarded as the social facet of sustainability, relationships and cultural collaborations that bind groups of these signals are similarlyassociated with feeble and robust sustainability.

In spite of the fact, wild nature, large forests, and hygienic land and water signify the real energy of the country and ought to be harnessed wisely for the development of 
green entrepreneurship. The sectors with most prospects for the development of green entrepreneurship are green energy, eco-agriculture, eco-tourism, education, consultancy and eco-products (Silajdžić et al., 2015). Environmental issues have grasped significant attention in corporate green operations. Innovation has become critical to the survival of firms and a weapon with which to preserve competitive advantage (Chiou et al., 2011; Kengatharan,2012). Environmental practices have been well acknowledged despite only very few studies have projected the green innovation practices of corporate firms (Tseng et al., 2013). Environmental challenges have grasped significant attention in corporate green processes (Tseng et al., 2013), additionally, environmental practices have been studied. Despite, finite studies have been elicited the green innovation interventions of corporate firms. Green innovation which was proven to be significant, while that of environmental performance remained insufficient (Lin and Chen, 2004).

\section{Research Gap}

Initially, entrepreneurship and the natural atmosphere were thought to be mismatched by economists, nevertheless, researchers recently have found that the two concepts can play significant role in modern economic development. Businesses are responsible for many environmental challenges like pollution and high material, water and energy consumption (Fatoki, 2019). This has directed to the development of green entrepreneurship, a business model that takes into consideration profit and environmental protection (Kirkwood and Walton, 2010). Novel business models are needed to compact the impact of business activities on the environment. Further, the harmful effects of climate change becoming progressively seeming, there is the urge for a sustainable shift in the current production and consumption systems Fatoki, 2019, the change into a green or sustainable economy requires to be led by entrepreneurs who can present innovative business solutions that will furnish to environmental and social challenges. Businesses have the long-term goal, technological knowledge and financial resources to provide solutions to environmental problems. Not with standing, the most of studies in green entrepreneurship are either case studies or conceptual studies focusing on innovation and concern for the environment and there are rarely found studies and analyses of large-scale quantitative studies focusing on the research trends on this field and it is this gap in the literature (Kumar and Kiran. 2017). Over the decades, countries with transition economies (e.g.- Sri Lanka) are strive to enhance entrepreneurial exertion that would foster exponential growth with least collision on natural resources. 
Notwithstanding, definite challenges the economics in transitions encounter, development of Sustainable entrepreneurship has not been in focus of the academic research (Silajdžić, Kurtagic, Vucijak, 2015; Kengatharan, 2013). Hall et al. (2010) highlighted that, sustainability has become an ordinary strategy in doing successful business and entrepreneurship is a phenomenal element for more sustainable society. Considering the modern evolving requirement to attain sustainability, it is acknowledged that entrepreneurship can be a solution for transition towards a more sustainable society. Furthermore, the researchers in the area of entrepreneurship have keen attention to the intertwine between firms and environment, specifically to the role of entrepreneurs in the development towards a more sustainable environmental, commercial, and economic system. It has been highlighted that, the number of green start-ups has progressively increased around the world with regards to the environmental issues demanding creative solutions (Demirel et al., 2019). Notwithstanding, the finite comprehension of firm's green innovation practices has hindered the development of a vastly recognized framework that would characterize and categorize firm's green innovation activities. Nonetheless, just a few studies have been found in the literatures that claim the drivers of firm's green innovations (Lin et al., 2011; Tseng, 2013). Hence, firms ought to be reinforce their competitiveness owing to the conditions of dynamical green technology and the short life-cycle of products.

\section{Research Questions}

The purpose of the study is to explore the influence of green innovation and entrepreneurship on sustainable development. Hence, this research focuses on answering the underneath main research questions;

- Does green innovation matter in green entrepreneurship sustainability?

- How does green innovation influence on green entrepreneurship sustainability?

- What are the consequences of green innovation in green entrepreneurship sustainability?

\section{Objectives of the Study}

- To discover relationship between green innovation on green entrepreneurship sustainability.

- To investigate how green innovative practices influence on green entrepreneurship sustainability. 
- To identify the consequences of green innovation in green entrepreneurship sustainability.

\section{Significance of the Study}

Investment in green economy afford an exclusive open door for emerging economics and countries in transition to accelerate compliance with global standards, while ensuring sustainable development. This signifies that firms in many industries encounter rigorous environmental and social pressures. Instead of focusing on shortterm profits, the entrepreneurs are anticipated to confront a triple- bottom line of economic, environmental, and social value creation. Therefore, the present study aims to provide an insight into the significance on green entrepreneurship and its impact on the sustainable development of the country.

\section{Theoretical Underpinning}

Innovation and entrepreneurship are two intertwined terms adopted in today's global business environment. Innovative entrepreneurs possess creative intelligence, which empowers discovery yet differs from other types of intelligence (Dyer et al., 2009). Innovation deemed as the key facetinreaping sustainable competitive advantage to enhance success of firms. The ultimate purpose of the innovation is generally to sustain, grow, and generate profit, however what matters for innovation is how it impact on the changes of survivals, revenue and development opportunities (Vadastreanu et al., 2015).Lisetchia and Brancub (2014) define innovation, refers to the newness across several facets of importance to the economy in terms of new products, a new quality of a good, new method of production, entering into new market, new sources of supply, half-manufactured goods and services, new form of organizations, new business models, and new management and marketing techniques. Difference ought to be made between radical innovations and incremental innovations. Radical innovations create significant technological breakthrough and incremental innovations encapsulates revamping existing products or services and knowledge (Lee et al., 2011).

\subsection{Concept of green innovation}

Green innovation has been vastly recognized as one of the vitally important strategic tools to grasp sustainable development in increasing environmental pressure (Chang, 2011). Green innovations enhance resource productivity and make firms more 
phenomenal (Porter and van der Linde 1995). Chen et al., (2006) highlighted that, green innovation can be categorized into two distinct facets, green products and process, encapsulating the technological innovation which involved in energy saving, pollution-prevention, recycling, green product designs, and corporate environmental management. Moreover, they epitomize green innovations are the ideal method to enhance the environmental performance to gratify the requisite of environmental regulations. Other studies have shown that, green innovation could be categorized into four facets: managerial innovation, product innovation, process innovation, and technological innovation (Ho et al., 2009; Yung et al., 2011). Moreover, Chen et al. (2012) categorize green innovation into two types: proactive and reactive innovations because their origins are different.

Green innovation can foster the environmental management performance. Fergusson and Langford (2016) highlighted that the, firms showcase the eagerness to adopt an environmental innovation strategy to foster business success. Therefore, the green innovation epitomizes the idea of environmental protection into the design and package of products to enhance their different benefits (Hart, 1995).Walley and Whitehead (1994) denote that the phenomenon green act as a change catalyst in the economyto foster successive innovation, creates new market opportunities, and creation of wealth.In further, precisely designed environmental standards can encourage entrepreneurs to launch green products and technologies, and it is vitally important to differentiate their products and services in terms of cost, price, and qualitythrough product and process innovations are crucial.According to Wong et al. (2013) green innovation which promotes a mitigation in a firms' influence on the environment, enabling the firm to attain eco-targets, and encompass environmental gains.If firms are eager to grasp green innovations ambitiously, they can implement green differentiation strategies and revamp the competitive regulations to garner competitive advantages (Porter and vander Linde, 1995; Porter, 1981).Tseng et al. (2013) emphasized that firms upgraded their green innovations to reinforce their competitiveness due to the realism of rapidly changing green technology and the petite lifecycle of products.Lamentably, green innovation encapsulates high market vagueness and risk, and resources are purchased in product and process improvement. These process and product innovations are the basis for real operations such as research and development activities (Berthon et al., 1999). Green innovation has been embodied as an effectual approach for firms to reap competitive advantage (Pujari, 2006). 
This intertwine between the innovations and operations cannot be neglected in a firm's environmental performance.Halila\&Rundquist (2011) in elaborating green innovation as a development and execution of new products and products and processes for the attainment of eco-targets and mitigation of the ecological footmark across the holistic manufacturing process and product lifecycle. Green innovations can promote the value of the product, and hence compensate the cost of environmental investments. As a result, green innovations can reinforce the corporate image and foster firms successful. Therefore, enhancing green innovations is a win-win solution for firms that confront the discrepancy between economic development and environmental preservation (Porter and van der Linde, 1995). Chen (2008) expound that green core competencies as the collective learning and potentialities regarding green innovation and environmental management.

\subsection{Concept of green entrepreneurship}

Entrepreneurship was first manifested by Joseph Schumpeter (1934). Entrepreneurship is a complicated concept to describe since, it is seen on various disciplines with different viewpoint. The concept of entrepreneurship was first reveled in the literature on individuals as entrepreneurs (Kirzner, 1973). Entrepreneur refers to an individual who visualizes new business opportunities and creates firms form sketch, with finite resources and works in an uncertain atmosphere (Schaper, 2002). Conversely, entrepreneurship is described through three fundamental concepts: innovativeness, risk taking, and proactiveness (Covin and selvin, 1989; Zahra, 1993). The phenomenon "green entrepreneurship" also known as environmental entrepreneurship (Enviro-preneurship), ecological entrepreneurship (Eco-preneurship), and sustainable entrepreneurship (Schaper, 2016; Pacheco, 2010). Schumpeter (1934) emphasize entrepreneurs bring creative destruction by holistically turning the admitted mode of business operations. The conception that entrepreneurs cannot be environmentally conscious, or don't care to be, is speedlay becoming outdated (Porter and van der Linde 1995; Anderson 1998). Intriguingly, a new type of entrepreneur denoted as green entrepreneur (ecopreneur) is combining an ambitious business sense with a consciousness of sustainability and other etiquette of the environmental progress. In further, ecopreneurs can be classified in a multifaceted way (Schaper, 2016). In spite of the observed speedy growth in the universal field of green study, green entrepreneurship, as a field of study is still at its infancy (Muo, Azeez, 2019). There has been an ever-increasing advocacy for favorable environment 
for biodiversity, which incited the embryonic of green arena of study courteousness of creative intelligence.

According to Chell (2008) sketching the green entrepreneur is a captivating theme; in further, risk-taking tendency, internal locus of control and need for achievement are considered as phenomenal entrepreneurial traits; conversely, in order to define green entrepreneurs, such factors taken into account (e.g.- specific environmental orientation). Not intriguingly, Chell(2008) manifest that there is no standard explanation of an "eco" entrepreneur, since the term is the consequence of the intimacy and unification of various environmental factors (Desai, 2009). Indeed, green entrepreneurs possess five typical inspirations; green values, discovery of opportunities in market, making a living, being as an own boss, and a passion for the firm, product or service (Kirkwood and Walton, 2010).

More so, foremost factor, green entrepreneurs take calculated risks in an uncertain environment. Secondly, their actions lead to a growing positive effect on the nature (eco-friendly), eventually, their personal values dependon the same basis (Schaper, 2016). In fact, Walley and Taylor (2002) highlight that preserving the environment is the fundamental consideration. Therefore, entrepreneurship to green progress from either being innovative or being aware of the environmental thinking (Carsrud\&Brannback, 2008).Green entrepreneurship has the appearance as the solution for sustainable development. Nacu\&Avasilcăi (2014) disclosed that the green production and sustainability possess high growth potential these slants have introduced a vast range of opportunities for entrepreneurs at the convergence of environment, social and economic goals, considers as eco-entrepreneurs. Green project (2012) defines green entrepreneurship as activities which are mindfully expressing environmental/social problems/needs via execution of entrepreneurial ideas twixt high risk and anticipation of positive impact on environment and financial sustainability.

\subsection{The concept of sustainability}

Sustainability therefore, is generally interpreted interchangeably with corporate social responsibility (CSR) despite lucidly it is a facet of the holistic picture. Sustainability is generically associated with the use of natural resources and problems corresponding with the environment. Sustainability is the asset of biological systems to remain disparate, diverse, diversified and productive indefinitely (Basdekidou, 
2017).According to Chandler and Werther (2014) in a broader way, defined as, meeting the needs of the present without compromising the ability of future generations to meet their own needs. More so, sustainability focus on the environment but its scope has been extended to encapsulates ethical, social issues, employee treatment, community involvement, and the organizational structure in place to control all the aspects (Kolk, 2008).

\section{Research Design and Methodology}

To achieve the above aforesaid objectives of the research, this study relayed on a qualitative approach. Intriguingly, the ideal qualitative studies enlighten the real problems at hand by the application and or development of a conceptual analysis (Fine, 2010). Qualitative analysis tent to be inductive rather deductive. Rather working from definite hypothesis and programmed coeds, thence the researcher codes the data whilst or later it has been gleaned. More so, coding schemes can frequently very intricate despite, are the key vital to the data analysis (See Lofland and Lofland, 1995; Strauss, 1987). Schein (1990) underscores the significance of using a qualitative approach to gather perceptions about organizational cultures among members of organizations.

\subsection{Instrument: (in-depth interview)}

Unprecedentedly, due to rapidly changing technologies and human interaction issues, there has been an urgent need for the timely evaluation of systems with distributed users in varying contexts (see Pace, 2004). This has stimulated the increased use of questionnaires, in-depth interviews and focus groups in commercial and academic research contexts. In-depth interviews defined as "repeated face-to-face confronts betwixt the informants and the researcher directed toward comprehending informants' perceptions and viewpoints on their lives, experiences or circumstances as reviled in their own words (Minichiello et al., 1990). The structure for an in-depth interview can take on many forms (e.g. scenario-led, reflective accounts, task-led). Yet there are some basic guidelines that can be followed for all of these approaches (Adams, Cox, 2008).Interviewing can garner the comprehensive in-depth information from the informants who know about their personal perception of events, processes, and the environments (Fine, 2010). The key feature of in-depth interviews is that they offer much more comprehensive information than what is accessible through other data collection methods, such as surveys (Boyce and Neale, 2006). In further, it can be an 
ideal method of examining information regarding intricate circumstances and one-toone condition, it provides an open-door to acquire and comprehend the specific subject, which is can't see in other methods.

\subsection{Population and sampling}

The population for this study encapsulates successful entrepreneurs in Vavuniya district. A total of eight $(\mathrm{N}=8)$ entrepreneurs were selected for the aforesaid purpose, relay on the infer of they possess the fundamental theoretical knowledge and understanding corresponding with the concepts of green innovation and green entrepreneurship and sustainability. It is pertinent and crucial for the success of such a study to use specific individuals with distinct knowledge and understanding of such an issue (Ritchie and Lewis, 2003; Creswell, 1998).

Garnering data is critical in research, because the data is underlaying to partake to a solid understanding of a theoretical framework (Bernard, 2002). In further, a critical problem is how to plan the sample and hire the informants for in-depth interviews. The rational for sampling using qualitative techniques varies from that for quantitative techniques. Therefore, samples are purposive and aim to choose informants that will manifest rich data (see Baum, 1998). The sample is flexible and evolves as the study develops, informed by analysis of data and guided by developing understandings. Therefore, purposive sampling has been embraced for the study. Notwithstanding, the use of the method is not sufficiently elaborated in most studies. Choosing the purposive sample is rudimentary to the quality of data garnered, henceforth, reliability and competence of the respondent must be ensured. Purposive sampling is typically exemplified via the key informant technique (Lyon and Hardesty, 2005), in which a few individuals are solicited to act as guides to a culture. And are willing to manifest their knowledge (Champbel, 1995; Tremblay, 1957).

\subsection{Mode of analysis}

The method of thematic analysis was used to identify themes and patterns from the transcriptions of the interview, and it was deductive. A thematic content analysis was employed for analyzing the transcripts. Qualitative content analysis and thematic analysis are two commonly used approaches in data analysis of nursing research (Vaismoradi and Turunen, 2013). The method of thematic analysis was used to identify themes and patterns from the transcriptions of the interview, and it was 
deductive. The following codes were developed based on the previous studies bygreen products and process, encapsulating the technological innovation which involved in energy saving, pollution-prevention, recycling, green product designs, and corporate environmental management Chen et al., (2006). The codes of green entrepreneurship were developed based on (Allen and Malin, 2008), including: low levels of interest in economic success; high degrees of awareness about the business's environmental impact. In addition, several constructs emerged, which included personal motivation and mission, locality, and a forward-thinking orientation about sustainability.

\section{Findings and Discussion}

Eight key informants grasped of this study where five of them were males and the remaining three were females. They were extraordinary informants per se originated from differing age groups, years of experience in the business, educational qualifications and gender. The highest number of informants fell between 30-40 age group ( $\mathrm{N}=3)$, followed by four informants $(\mathrm{N}=2)$ between $40-50$ and the remaining two informants $(\mathrm{N}=3)$ were over 50 age group. Average years of experience were 6 years.At the beginning, the key informants at large were asked to disclose their general view towards their business (entrepreneurial) profession. Thence, how green innovation and its practices affect green entrepreneurial success, and consequently sustainable development. It is vitally important to enquire about these concepts and its' consequences to investigate the effect on the environment to provide robust solution to the problem in the form of recommendation to enhance environmental consciousness to reap entrepreneurial success.

\section{One informant disclosed that,}

Of course, "we are environmentally conscious, and we know the value of the environment. But we never had any innovative practices to protect the environment. Not only by us but the whole business people. For instance, we are still packaging the products using plastic materials, thence how we can say that we adopt green innovation? We haven't carried out any reforms to create any green services".

(Informant-5)

The implementation of green innovations represents an important challenge for nongreen companies because it often requires the acquisition of new resources and 
competences that differ significantly from the competences already owned. Green entrepreneurship can be best studied through case studies, field visits, inquiry, interaction with society and through interactions with the practitioners in this field. It is of various type and nature.

\section{It has been said by an informant}

"I haven't introduced any green innovative products and services to the market. Despite, I have no idea regarding green innovation, green entrepreneurship and sustainability. Because I have no education qualification and I have not attended any training and development session regarding this. Thus, I am not well aware about these concepts. And this is the first time I heard these ones".

(Informant-1)

There are some Green entrepreneurs, who are engaged in the sphere of public policy. There are some who are engaged in raising public voice for social change. Some are engaged in development of new products and services for the overall benefit of the society. present growing need to achieve sustainability,it is recognized that entrepreneurship can be a panacea for transition towards a more sustainable society.

\section{According to one informant}

"We had a great idea regrading green innovation to foster our business success and reputation, since my background is management. The critical obstacle I encountered money (Finance). To execute our innovative plan regarding green we ultimately require support from the government in terms of finance. If we have financial assistance in future, we will execute our green plans".

(Informant-3)

Green entrepreneurship can provide solutions to youth unemployment and sustainability pertaining to the low entry - level requirements for entrepreneurs in several green sectors and their interest in innovative business solutions and sustainability deliberations.

\section{Another informant reviled that}

"We are operating our business as the way it is. We never wanted to engage in these. Because of my age (old) I can't take risk alone. Moreover, it requires solid 
knowledge and mindfulness about green innovation which I haven't. In further, we have no management department to carry out these things.

\section{One informant disclosed that}

(Informant-4)

"Our primary aim is customer satisfaction and through that generating profit. We consider the eco-friendly environment through CSR activities. Moreover, we don't adopt any green practices and we are not conscious about the green innovation and green entrepreneurship."

(Informant-2)

Some green entrepreneurs are engaged in the fields of education and employment generation. Most entrepreneurs in the field of environment development are in the sectors where the governments open opportunities for people to come and work for environment development.

"We adopt green innovative practices. Genuinely, we are not in sufficient level. Because of the fear of failure and taking risk. Moreover, it is the government responsibility to foster the green practices."

(Informant-7)

Green entrepreneurs have to negotiate tensions between their business activities, their environmental philosophies and these wider contexts relating to the green economy andthe mainstream, growth-focused economy. They identified as new entrepreneurial actors seeking to combine environmental awareness and business in a holistic manner and are said to havea different organizing logic to more conventional entrepreneurs.

\section{One of the entrepreneurs expressed:}

"Even though government impose the solid green innovative practices, they fail to examine the effectives of their initiatives, right? And Therefore, going for green nature is depends not merely on the entrepreneurs but government as well".

(Informant-8)

Green entrepreneurs driven by environmental concerns stand at the heart of greening the economic activities right from their inception. The traditional efforts to endure greater obligation on social, economic and environmental dimensions in production and consumption practices focused predominantly on "why" and "how" the existing enterprises can become "greener". However, it was realized that a green economy 
cannot be forged without addressing the issues of sustainability in small, medium and large-scale businesses right from their inception.

\section{Another Informant's Verbatim Quote:}

"We have attended several training and workshop regarding the green entrepreneurial activities and we had the certificates as well.However, to implement the project we require finance and good knowledge on the concepts. Therefore, we ignored the project and still we adopt the traditional methods of the production."

(Informant-6)

\section{Conclusion}

Natural environmental issues are increasingly becoming integral part of business in every passing day without being recognized as such. It has been argued by many scholars that holistic green business solutions that add value to organizations and their stakeholders should be made part of the basic system of business. Unprecedentedly, many businesses in many industries encounter raised environmental and social uncertainties. Scientific evidence regarding adverse environmental impacts of economic development (e.g. accelerated climate change, sea level rise, deforestation) has led to increased awareness and concern amongst policy makers. More so, businesses ought to be focus on triple-bottom line of economic, environmental, and social value creation rather concerning profits. Considerable consideration has focused on low carbon initiatives - an attempt to reduce greenhouse gas emissions and so mitigate climate change - and the development of a green economy (Davies and Mullin, 2011). There has been an expanding literature on green entrepreneurship which argues that individuals who combine environmental awareness with entrepreneurial action will form a key driver in any move towards a green economy (see Schaper, 2010).

The finding proposes insufficient investments and promotion that can foster the green entrepreneurship. This highlights that the risk-taking propensity in transition economies is comparatively higher than to that of developed economics. Therefore, there is an urge to elicit creativity and innovation to mitigate the probability of failures. In the absence of economic change frame conditions (taxes, incentives and legislations) it is questionable that eco-innovations in business will replace the conventional technologies (Silajdžić, Kurtagic, Vucijak, 2015). Moreover, the finding 
disclosed that shortcomings in starting up a business is remaining high due to many reasons(lank of finance, lack of business know-how, lack of managerial know-how, lack of creativity and innovation, and lack of motivation).Greening is a form of innovation that requires behavioral changes and habit modification, it is necessary to understand how these change process unfolds hence, need for change management expert's contribution to the field of greening.

\section{Recommendation}

Lucidly, there is a gap in addressing the concept of sustainability in management and business education. The transformation of entrepreneurship related curricula in higher education institutions must take place in order to meet the increasing social demands for responsible business. Education should also be directed toward decision makers in order to facilitate the creation of favorable environment for green entrepreneurship (Silajdžićet al., 2015). It can be epitomizing that entrepreneurs generate employment opportunities, introduce innovative products and services, reduce the pressure of balance of payment, balance reginal development, act as a change catalyst to foster economic growth, and so forth. Therefore, country's prosperity relays on entrepreneurial thrust. Thus, intervention of government in various methods can stimulate entrepreneurial success and eventually sustainability.

It is pivotally prominent to foster students required knowledge and understanding regarding "green" innovation and entrepreneurship in school curricula and more specifically in universities. Because finding reviled that the informants have lack of knowledge and conscious on the green and its impact on the environment. An ideal way of making the conscious thought about entrepreneurial success and environmental sustainability is exquisite education. Government should facilitate the training, development, workshop, and seminars (e.g. technology and new product development)and green innovative policies, rules and regulations to embrace green entrepreneurship which stimulate environmental sustainability. Additionally, governmental departments or NGO can promote green practices to foster eco-friendly environment. More specifically, it ought to be provided the financial assistance, grants and or proper guidance to the entrepreneurs to embrace change (e.g. adopting new technology). Incentives by government can also foster green innovation and green entrepreneurship.

Journal of Business Studies, 7(1)

$-141-$

2020 
Dissemination of information on green innovation and green entrepreneurship is thus, inevitable to confront environmental responsibilities. Notwithstanding, an entrepreneurs' generic and fundamental quality is thus innovation. More so, entrepreneurship success depends on the entrepreneurs' innovation, risk taking, relentless agility and so forth. Therefore, they ought to seek ways to reinforce their instinct qualities to elevate business success. Exchange of knowledge about green innovation, green technology, green products and production and green entrepreneurship by inviting the successful green entrepreneurs form foreign countries can also be a better solution to enhance green entrepreneurial growth. More specifically, it ought to be eradicated the green washing in entrepreneurship. "green washing" recognized as "economic fraud" because any firm which luxuriate in it technically would repudiate its environmental responsibilities due to the fake belief that the cost of being eco-friendly or responsible is insignificant to accept. O'Neil and Ucbasaran (2016).

Greenwashing persists a misleading marketing device and unscrupulous profitgenerating process in the firms' green marketing efforts. Henceforth, greenwashing jeopardizes entrepreneurship success. Therefore, government can intervene to dampen the unscrupulous business operation to preserve the nature and to foster entrepreneurial growth. This can be beneficial for short term survival but in long term this can be questionable. Hence government should implement rigorous policies and regulations. 


\section{References:}

Adams, A., \& Cox, A. L. (2008). Questionnaires, in-depth interviews and focus groups, Cambridge University Press.

Anderson, A. (1998). Cultivating the garden of eden: Environmental entrepreneuring. Journal of Organizational Change Manage. 11 (2), 135 - 144.Basdekidou, V. A. (2017).

Green entrepreneurship \& corporate social responsibility: Comparative and correlative performance analysis. International Journal of Economics and Finance, 9(12), 1-12.

Baum, F. (1998). The new public health: An Australian perspective. Melbourne, Australia: Oxford UniversityPress.

Bernard, H.R. 2002. Research Methods in Anthropology: Qualitative and quantitative.

Boyce, C., \& Neale, P. (2006). Conducting in-depth interviews: A guide for designing and conducting in-depth interviews for evaluation input, Pathfinder International Watertown, MA.

Campbell, D.T. (1955). The informant in quantitative re- search. The American Journal of Sociology, 60, 339-342.

Carsrud, A. L., Brännback, M., \&Renko, M. (2008). Strategy and strategic thinking in biotechnology entrepreneurship. In Handbook of bioentrepreneurship (pp. 83103). Springer, New York, NY.

Chandler, D., \& Werther Jr, W. B. (2013). Strategic corporate social responsibility: Stakeholders, globalization, and sustainable value creation. Sage Publications.

Chang, C. H. (2011). The influence of corporate environmental ethics on competitive advantage: The mediation role of green innovation. Journal of Business Ethics, 104(3), 361-370.

Chell, E. (2008), The Entrepreneurial Personality A Social Construction, 2nd edition, Routledge, Psychology Press, London.

Chen, Y. S. (2008). The driver of green innovation and green image Green core competence. Journal of Business Ethics, 81(3), 531-543. 
Chen, Y. S., Lai, S. B., \& Wen, C. T. (2006). The influence of green innovation performance on corporate advantage in Taiwan. Journal of Business Ethics, 67(4), 331-339.

Chiou, T. Y., Chan, H. K., Lettice, F., \& Chung, S. H. (2011). The influence of greening the suppliers and green innovation on environmental performance and competitive advantage in Taiwan. Transportation Research Part E: Logistics and Transportation Review, 47(6), 822-836.

Creswell, J. (1998). W.(1998). Qualitative inquiry and research design: Choosing among five traditions, 2 .

Demirel, P., Li, Q. C., Rentocchini, F., \&Tamvada, J. P. (2019). Born to be green: new insights into the economics and management of green entrepreneurship. Small Business Economics, 52(4), 759-771.

Desai, V. (2009). Dynamics of entrepreneurial development and management (pp. 6693). Himalaya Publishing House.

Dyer, J. H., Gregersen, H. B., \& Christensen, C. (2009). Entrepreneur behaviors, opportunity recognition, and the origins of innovative ventures. Strategic Entrepreneurship Journal, 2(4), 317-338.

Fergusson H., Langford D., (2016). Strategies for managing environmental issues in construction organizations, Engineering. Construction and Architectural Management, 13, 171-185.

Fatoki, O. (2019). Green entrepreneurial orientation and firm performance in SouthAfrica. Entrepreneurship and Sustainability Issues, 7, 247-262.

Haldar, S. (2019). Green entrepreneurship in the renewable energy sector-a case study of Gujarat. Journal of Science and Technology Policy Management.

Halila, F., \&Rundquist, J. (2011). The development and market success of eco -innovations. European Journal of Innovation Management.

Hall, J. K., Daneke, G. A., \& Lenox, M. J. (2010). Sustainable development and entrepreneurship: Past contributions and future directions. Journal of Business Venturing, 25(5), 439-448.

Hart, S. L. (1995). A natural-resource-based-view of the firm. Academy of Management Review, 20, 986-1014. 
Ho, J. C., Shalishali, M. K., Tseng, T., \& Ang, D. S. (2009). Opportunities in green supply chain management. The Coastal Business Journal, 8(1), 18-31.

Jain, T. K. (2018). Towards the Theory of Green Entrepreneurship. Available at SSRN 3284935 .

Katila, R., Chen, E. L., \&Piezunka, H. (2012). All the right moves: How entrepreneurial firms compete effectively. Strategic Entrepreneurship Journal, 6(2), 116-132.

Kengatharan, N. (2012), Exploring the relationship between Psychological Characteristics and Entrepreneurial Inclination: A Case Study from Sri Lanka. Global Journal of Management and Business Research, 12(21), 83-89.

Kengatharan, N. (2013), Structuring Latent Nature of Planning Competencies of Business Operators and its Impact on Business Performance: Evidence from Sri Lanka. International Journal of Applied Research in Business Administration and Economics,2(2), 1-13.

Kirkwood, J., and Walton, S. (2010). What motivates ecopreneurs to start businesses?", International. Journal of Entrepreneurial Behaviour\&Research, 16(3), 204-228.

Kirzner, I.M., 1973. Competition and Entrepreneurship. University of Chicago press, Chicag.Kolk, A. (2008). Sustainability, accountability and corporate governance: exploring multinationals' reporting practices. Business strategy and the environment, 17(1), 1-15.

Kumar, A. and Kiran, P., Green Entrepreneurship: A Bibliometric Study.

Lee, L., Wong, P. K., Der Foo, M., \& Leung, A. (2011). Entrepreneurial intentions: The influence of organizational and individual factors. Journal of business venturing, 26(1), 124-136.

Lisetchi, M., \&Brancu, L. (2014). The entrepreneurship concept as a subject of social innovation. Procedia-Social and Behavioral Sciences, 124(0), 87-92.

Lofland, J., \&Lofland, L. H. (1995). Developing analysis. Analyzing social setting, 183-203.

Journal of Business Studies, 7(1)

$-145-$

2020 
Lyon, L. M., \& Hardesty, L. H. (2005). Traditional healing in the contemporary life of the Antanosy people of Madagascar. Ethnobotany Research and Applications, 3, 287-294.

Maier, D., Vadastreanu, A. M., Keppler, T., Eidenmuller, T., \& Maier, A. (2015). Innovation as a part of an existing integrated management system. Procedia Economics and Finance, 26, 1060-1067.

Minichiello, V., Aroni, R., Timewell, E., \& Alexander, L. (1990). In-depth interview: researching people. Cheshire, UK.: Longman.

Mrkajic, B., Murtinu, S., \&Scalera, V. G. (2019). Is green the new gold? Venture capital and green entrepreneurship. Small Business Economics, 52(4), 929-950.

Muo, I., \& Azeez, A. A. (2019). Green Entrepreneurship: Literature Review and Agenda for Future Research. International Journal of Entrepreneurial Knowledge, 7(2), 17-29.

Nacu, C.M., and Avasilcăi, S. (2014). Technological ecopreneurship: conceptual approaches", Procedia - Social and Behavioral Sciences, 12(4), 229-235.

O'Neil, I., \&Ucbasaran, D. (2016). Balancing "what matters to me" with "what matters to them": Exploring the legitimating process of environmental entrepreneurs. Journal of Business Venturing, 31(2), 133-152.

Pace, S. (2004). A grounded theory of the flow experiences of Web users. International journal of human-computer studies, 60(3), 327-363.

Pacheco, D. F., Dean, T. J., \& Payne, D. S. (2010). Escaping the green prison: Entrepreneurship and the creation of opportunities for sustainable development. Journal of Business Venturing, 25(5), 464-480.

Porter, M. E. (1981). The contributions of industrial organization to strategic management. Academy of management review, 6(4), 609-620.

Porter, M. E., \& Van der Linde, C. (1995). Toward a new conception of the environment-competitiveness relationship. Journal of economic perspectives, 9(4), 97-118.

Porter, M., \& C. Van der Linde. (1995). Green and com- petitive. Harvard Business Review, 73(5), 120-134. 
Ritchie, J., Lewis, J., \& Elam, G. (2003). Designing and selecting samples (pp. 77108). London: Sage.

Schaper, M. (2002). The essence of ecopreneurship. Greener management international, 26-30.

Schaper, M. (Ed.). (2016). Making ecopreneurs: Developing sustainable entrepreneurship. CRC Press.

Schein, E.H. (1990). Career Anchors: Discovering Your Real Values, Pfeiffer and Company, San Diego, CA.

Schumpeter, J.A., 1934. The Theory of Economic Development. Harvard University Press, Cambridge, MA.

Silajdžić, I., Kurtagic, S. M., \&Vucijak, B. (2015). Green entrepreneurship in transition economies: a case study of Bosnia and Herzegovina. Journal of Cleaner Production, 88, 376-384.

Strauss, A. L. (1987). Qualitative Analysis for Social Scientists. Cambridge: Cambridge University Press.

Taylor, D. W., \& Walley, E. E. (2004). The green entrepreneur: opportunist, maverick or visionary?. International Journal of Entrepreneurship and Small Business, 1(12), 56-69.

Tongco, M. D. C. (2007). Purposive sampling as a tool for informant selection. Ethnobotany Research and applications, 5, 147-158.

Tremblay, M. A. (1957). The key informant technique: a non-ethnographic application. American Anthropologist, 59, 699-701.

Tseng, M. L., Wang, R., Chiu, A. S., Geng, Y., \& Lin, Y. H. (2013). Improving performance of green innovation practices under uncertainty. Journal of cleaner production, 40, 71-82.

Vaismoradi, M., Turunen, H. and Bondas, T., 2013. Content analysis and thematic analysis: Implications for conducting a qualitative descriptive study. Nursing \& health sciences, 15(3), pp.398-405.

Walley, E. E., \& Taylor, D. W. (2002). Opportunists, champions, mavericks...? Greener Management International, (38). 
Walley, N., \& Whitehead, B. (1994). It's not easy being green. Reader in Business and the Environment, 36(81), 4.

White, M. D., \& Marsh, E. E. (2006). Content analysis: A flexible methodology. Library trends, 55(1), 22-45.

Wong, C. W., Wong, C. Y., \& Boon-itt, S. (2013). The combined effects of internal and external supply chain integration on product innovation. International Journal of Production Economics, 146(2), 566-574.

Zahra, S. A. (1993). Environment, corporate entrepreneurship, and financial performance: A taxonomic approach.Journal of business venturing,8(4), 319340.

Kirkwood, J., \& Walton, S. (2010). What motivates ecopreneurs to start businesses? International Journal of Entrepreneurial Behavior \& Research. 